Article

\title{
Road Trip in China: The Mediation Effect of Perceived Value and Tourist Satisfaction on the Relationship between Destination Image and Loyalty
}

\author{
Bin Wang ${ }^{1}$, Zhaoping Yang ${ }^{1,}{ }^{*}$, Fang Han ${ }^{1}$ and Hui Shi ${ }^{1}$ \\ 1 Xinjiang Institute of Ecology and Geography, Chinese Academy of Sciences, Urumqi 830011, China; \\ wangbin2014@mails.ucas.ac.cn (B.W.); hanfang@ms.xjb.ac.cn (F.H.); shihui@ms.xjb.ac.cn (H.S.) \\ * Correspondence: yangzp@ms.xjb.ac.cn (Y.Z.); Tel.: +86-991-788-5472
}

\begin{abstract}
This study aims to test a model linking destination image, perceived value, tourist satisfaction, and tourist loyalty. Based on a sample of 300 tourists travelling by car from the World Natural Heritage Site of Tianchi, China, a new model of destination image was explored and data were analyzed using Partial Least Squares Structural Equation Modeling (PLS-SEM). The results revealed that perceived value and satisfaction are the direct antecedents of destination loyalty. Above all, perceived value and tourist satisfaction mediate the relationship between destination image and tourist loyalty. Finally, this study discusses the theoretical and management implications to boost the tourism industry in the car trip context.
\end{abstract}

Keywords: Road trip; Destination image; Perceived value; Tourist satisfaction; Destination loyalty; China

\section{Introduction}

Automobiles create recreational and leisure opportunities [1]. Owning a car plays a significant role in daily lives [2]. In China, car tourism has increased with society development and has become a key driver of the country's economic development. The number of tourists travelling by car has reached 2.35 billion, accounting for $58.5 \%$ of the total number of domestic tourists in China in 2015. Furthermore, tourists travelling by car are the largest tourist group within the background of the sustainable growth of China's tourism industry according to China's Driving Tourism Development: Analysis and Forecast (2015-2016).

Xinjiang, the western province of China, is equivalent to one-sixth of the total area of the country. Xinjiang is close to Europe, at the heart of Silk Roads, the Routes Network of the Chang'an-Tianshan Corridor. The area has abundant natural resources (snow mountains, forest, desert, and meadow) and cultural attractions (ruins, beacon towers, ancient graves) [3]. For example, Tianshan was listed on the World Nature Heritage Site List by the United Nations Educational, Scientific, and Cultural Organization (UNESCO), World Heritage Centre, in 2013 [4], for the spectacular snow-capped mountains and glacier-capped peaks, beautiful forests and meadows, clear river and lakes, and grand red bed canyons. This confirms that this region possesses vast land resources, crucial location, and unique tourist resources in the world. Therefore, drive tourism is highly developed in this area.

Car trips are becoming increasingly popular. The area offers not only scenic spots and byways, and high-quality roads, but also tourist distribution centers, campgrounds, and service stations. In addition, the slogan of "Xinjiang in Great Beauty, Paradise for Car Trip" has been introduced to establish the destination image. These features suggest that car tour has the most promising growth prospects and potential in the tourism industry. 
Current research on car trip has discussed the concept and classification, the behavioral characteristics of tourists, travel routes characteristics, impacts and management of the phenomenon, and tourist satisfaction.

Many studies focused on the relationship among destination image, perceived value, tourist satisfaction, and tourist loyalty from different perspectives [5, 6]. However, very few studies explain these relationships from a different perspective, specifically focusing on car trip. Therefore, to fill the gap in the existing literature, this study focuses on the relationship among destination image, perceived value, tourist satisfaction, and tourist loyalty in the drive tourism context. In addition, the mediation effect of perceived value and satisfaction on the relationship between destination image and tourist loyalty are tested by targeting tourists travelling by car.

\subsection{Destination image}

Destination image can be defined as the series of impressions or perceptions of a tourist destination. It is a significant concept that plays an important role in a tourist's decisions. Previous studies have shown that destination image has been a significantly important topic in the field of travel studies, and scholars have tried to develop a conceptual framework for destination image through different methods. According to the study of Echtner and Ritchie, destination image is composed of attribute and holistic aspects [7]. For example, Gallarza and Saura evaluated destination image by using cognitive and affective aspects [8]. However, there was no agreement on the conception of destination image.

Sanz, Blas, and Carvajal-Trujillo showed that destination image was estimated along four dimensions: tourist resources, urban environment, infrastructure and atmosphere of the city, and socioeconomic environment [9]. In addition, Toudert and Bringas-Rábago used three dimensions: tourism resources, urban environment, and infrastructure and atmosphere [10]. According to the tourism system model, transport system is an important component in the functional tourism system model. Accessibility has a great influence on the tourism industry. This study suggests that the main elements considered by tourists travelling by car include tourist resources, accessibility, infrastructure, and travel environment [11].

As universally acknowledged, subjective perception, tourist experience, and destination familiarity are affected by destination image. In turn, destination image will affect tourists in the process of choosing a destination, in their subsequent evaluation, and future visit intentions. Destination image also has a significant impact on perceived value, tourist satisfaction, and tourist loyalty [12].

\subsection{Perceived value}

Perceived value is described as the overall assessment made by tourists on the basis of their comparison between the utilities or benefits and the perceived costs or sacrifices associated with a destination. From the utilitarian perspective, value scales embody both monetary costs [13] and nonmonetary costs (such as effort or time) [14]. Duman and Mattila found that perceived quality and monetary value are two main antecedents of perceived value [15]. Chen and Tsai measured perceived value using a three-item scale (money, time, and effort) [16]. Clemes and Brush used a single item for perceived value [17]. Sun and Geng-Qing Chi proposed a two-item scale for perceived value, including functional value and overall value [11].

Perceived value is an important antecedent to satisfaction and loyalty. Some researchers have shown that perceived value influences loyalty both directly and indirectly [18]. The relationship among perceived value, satisfaction, and loyalty has been examined by researchers who focused on the relating paths between perceived value and satisfaction [6], and between perceived value and loyalty [19]. 


\subsection{Satisfaction}

Satisfaction is defined as an overall judgment on products and services in a destination, and it is one of the most significant concepts of modern marketing competitiveness. Tourist satisfaction has been extensively researched in the tourism field [20]. There is a wide consensus on the fact that tourists' satisfaction has a crucial influence on tourists' loyalty or future behavioral intentions [21]. For example, satisfied tourists may give positive feedback about the destination, recommend it to relatives and friends, and revisit the same destination in the future. On the contrary, dissatisfied tourists may not recommend the destination to others, and may not return. In addition, dissatisfied tourists may demolish the brand image of a destination, so that its market suffers an adverse impact [22].

In contrast with past studies that included a single item, "overall satisfaction," to analyse the links described above [13], more recent researches used a combination of items [23]. However, to the best of our knowledge, no study has looked into the relationships between satisfaction and loyalty in the context of Chinese drive tourism.

\subsection{Loyalty}

Loyalty is described as a key element to acquire success in marketing and in tourism. Oliver defined loyalty as the highest level of commitment [24]. In the most recent literature, scholars proposed that loyalty is more complex and may include both attitudinal and behavioral loyalty [25].

In the literature on marketing and tourism, tourist loyalty is fully interchangeable with behavioral intentions. Loyalty, or behavioral intention, has been measured by positive word-ofmouth, recommendation to others, and purchase or revisit intention [26].

Therefore, more recent studies focus on the antecedents of loyalty, such as image, value, quality, trust, and satisfaction. For the theoretical framework, three antecedents are chosen as crucial factors in this study, including destination image, perceived value and tourist satisfaction.

According to this theoretical framework, the following hypotheses were proposed in the context of drive tourism:

H1: The higher destination image, the higher perceived value;

H2: The higher destination image, the higher tourist satisfaction;

H3: The higher destination image, the higher tourist loyalty;

H4: The higher perceived value, the higher tourist satisfaction;

H5: The higher perceived value, the higher tourist loyalty;

H6: The higher tourist satisfaction, the higher tourist loyalty;

H7: Perceived value and tourist satisfaction mediate the relationship between destination image and tourist loyalty. 


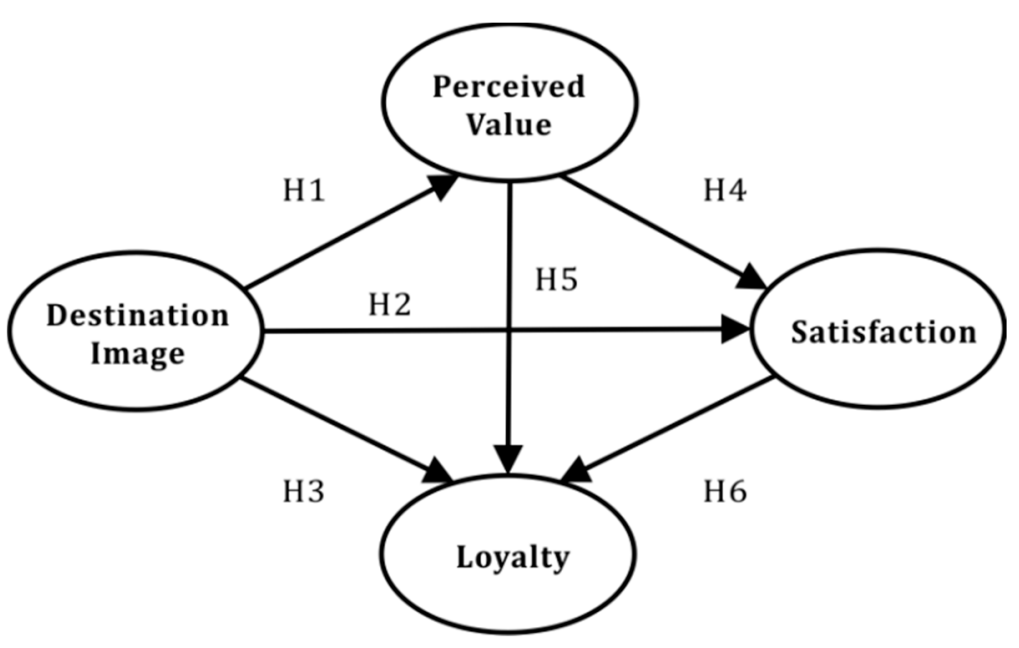

Figure 1. Conceptual model and research hypotheses

\section{Materials and methods}

\subsection{Questionnaire design}

A self-administrated questionnaire survey was designed to collect empirical data on drive tourism (See Table 1). The questionnaire was pre-tested using 89 respondents' information and it has been constantly revised to ensure content validity. In addition, several irrelevant or ambiguous items were cancelled to ensure clarity. The questionnaire consisted of five parts. Part 1 measured the destination image, with 20 items. Part 2 assessed the perceived value using 2 items. Part 3 evaluated the satisfaction measurement, with 3 items. Part 4 dealt, with the measurement of tourist loyalty, with 3 items. The first four parts were measured on a 5-point Likert-type scale: from 1-strongly disagree to 5 -strongly agree. Finally, Part 5 collected respondent information, with 6 items including gender, age, monthly income, education level, place of origin, and marital status.

Table 1. Constructs, items, labels, and sources

\begin{tabular}{lll}
\hline Constructs & Items \& Labels & Sources \\
\hline Destination image (DEI) & & \\
Infrastructure (INF) & Convenient wireless network（INF1） & [10, 19] \\
& Good mobile phone communication（INF2） \\
& Excellent travel websites（INF3） \\
& Tidy restrooms（INF4） \\
& High-class information centers（INF5） \\
& Standardized servicing stations（INF6） \\
& Wide variety of shop facilities（INF7） \\
& Wide choice of accommodations（INF8） \\
& Variety of entertainment（INF9） \\
\hline
\end{tabular}




\begin{tabular}{|c|c|}
\hline \multirow[t]{4}{*}{ Environment (ENV) } & Orderly administration (ENV1) \\
\hline & Good service (ENV2) \\
\hline & Clean and unpolluted environment (ENV3) \\
\hline & Tranquil and restful atmosphere (ENV4) \\
\hline \multirow[t]{4}{*}{ Accessibility (ACC) } & Moderate traffic flow (ACC1) \\
\hline & Spacious freeways (ACC2) \\
\hline & Identified road signs and indicators (ACC 3 ) \\
\hline & Ample parking spaces (ACC4) \\
\hline \multirow[t]{3}{*}{ Attractions (ATT) } & Unique ethnic culture (ATT1) \\
\hline & Fabulous scenic drive (ATT2) \\
\hline & Historic landmarks and sites (ATT3) \\
\hline \multirow[t]{2}{*}{ Perceived Value (PEV) } & Value for time (PEV1) \\
\hline & Value for money (PEV2) \\
\hline \multirow[t]{3}{*}{ Satisfaction (SAT) } & Overall satisfaction (SAT1) \\
\hline & Expectancy-Satisfaction (SAT2) \\
\hline & Right decision (SAT3) \\
\hline \multirow[t]{3}{*}{ Loyalty (LOY) } & Positive comment (LOY1) \\
\hline & Recommendations (LOY2) \\
\hline & Revisit intention (LOY3) \\
\hline
\end{tabular}

\subsection{Data collection}

Data were collected from Tianchi, Xinjiang Tianshan, which is a World Natural Heritage Site in China, using an intercept approach. Investigators submitted a questionnaire to tourists travelling by car, individual travelers, or community residents until the sampling goal was achieved. Data from 300 respondents were tested with the proposed model.

\subsection{Data analysis}

Descriptive statistics, including frequencies and distributions, were used to represent the demographic profile of the respondents. Exploratory factor analysis (EFA) with varimax rotation was performed for the underlying dimensions of destination image. In the present study, structural models were analyzed with the use of Partial Least Squares Structural Equation Modeling (PLS-SEM), rather than the Covariance-Based Structural Equation Model (CB-SEM), since PLS-SEM has runs computations more efficiently and faster than CB-SEM [29]. Both the measurement and structural models were tested using the SmartPLS 3.0 in this study. 


\section{Results}

\subsection{Descriptive analysis}

The respondents' profile shows an equal distribution in terms of gender: male $(49.7 \%)$ and female (50.3\%). There were two dominant age groups: between 31 and 50 years old (51.3\%) and 30 years old or younger (46\%). Nearly half of the respondents $(47.0 \%)$ had a monthly income between 3001 and 6000 China Yuan (CNY) and approximately one third of the respondents (31.3\%) had a monthly income of less than 3000 CNY. With the only exception of $4.7 \%$ of respondents, almost everybody in the sample held a high school degree, or higher. The majority of tourists concentrated within the Xinjiang Province (68.7\%). Last, more than half of all respondents is married (60.3\%) (See Table 2).

Table 2. Demographic profile of respondents $(n=300)$

\begin{tabular}{|c|c|c|}
\hline Items & Frequency & Percentage (\%) \\
\hline \multicolumn{3}{|l|}{ Gender } \\
\hline Male & 149 & 49.7 \\
\hline Female & 151 & 50.3 \\
\hline \multicolumn{3}{|l|}{ Age } \\
\hline Under 31 & 138 & 46.0 \\
\hline $31-40$ & 73 & 24.3 \\
\hline $41-50$ & 81 & 27.0 \\
\hline Over 50 & 8 & 2.7 \\
\hline \multicolumn{3}{|l|}{ Income (Monthly) } \\
\hline Under CNY 3001 & 94 & 31.3 \\
\hline CNY 3001-6000 & 141 & 47.0 \\
\hline CNY 6001-9000 & 42 & 14.0 \\
\hline CNY 9001 or over & 23 & 7.7 \\
\hline \multicolumn{3}{|l|}{ Education } \\
\hline Middle school or below & 14 & 4.7 \\
\hline High school & 87 & 29.0 \\
\hline Undergraduate & 142 & 47.3 \\
\hline Postgraduate & 57 & 19.0 \\
\hline
\end{tabular}




\section{Province}

Within the province

Outside the province

\section{Marital status}

Single

\subsection{Exploratory factor analysis}

To explore the underlying dimensions of destination image, Exploratory Factor Analysis (EFA) was carried on with the use of SPSS 19.0 for windows. Four factors, with a cut-off factor loading of 0.5 and an eigenvalue greater than one, explained $67.173 \%$ of the variance of the destination image scale through a principal components factor analysis with varimax rotation. The Cronbach's alpha was above the threshold value of 0.7 , confirming the high reliability of the results [29]. Table 3 presents the four factors mentioned above, labeled as infrastructure, environment, accessibility, and attractions.

Table 3. EFA Results on destination image

\begin{tabular}{|c|c|c|c|c|}
\hline \multirow{3}{*}{ Factor/ Item } & \multirow{3}{*}{ Factor Loading } & Variance & \multirow{3}{*}{ Eigenvalue } & \multirow{3}{*}{$\begin{array}{l}\text { Cronbach's } \\
\text { alpha }\end{array}$} \\
\hline & & & & \\
\hline & & explained (\%) & & \\
\hline Factor 1: Infrastructure（INF） & & 49.762 & 9.952 & 0.928 \\
\hline INF1 & 0.824 & & & \\
\hline INF2 & 0.790 & & & \\
\hline INF3 & 0.714 & & & \\
\hline INF4 & 0.659 & & & \\
\hline INF5 & 0.641 & & & \\
\hline INF6 & 0.610 & & & \\
\hline INF7 & 0.549 & & & \\
\hline INF8 & 0.548 & & & \\
\hline INF9 & 0.515 & & & \\
\hline Factor 2: Environment（ENV） & & 6.733 & 1.347 & 0.836 \\
\hline ENV1 & 0.776 & & & \\
\hline
\end{tabular}




\begin{tabular}{|c|c|c|c|c|}
\hline ENV2 & 0.742 & & & \\
\hline ENV3 & 0.727 & & & \\
\hline ENV4 & 0.607 & & & \\
\hline Factor 3: Accessibility（ACC） & & 5.524 & 1.105 & 0.820 \\
\hline ACC1 & 0.770 & & & \\
\hline ACC2 & 0.748 & & & \\
\hline ACC3 & 0.699 & & & \\
\hline $\mathrm{ACC} 4$ & 0.559 & & & \\
\hline Factor 4: Attractions（ATT） & & 5.154 & 1.031 & 0.724 \\
\hline ATT1 & 0.815 & & & \\
\hline ATT2 & 0.721 & & & \\
\hline ATT3 & 0.575 & & & \\
\hline
\end{tabular}

Note: Total explained variance $=67.173 \% ; K M O=0.945$.

\subsection{Measurement model}

To estimate the constructs, the reliability and construct validity of the conceptual model were tested using PLS. The internal consistency was examined using Composite Reliability (CR), whose recommended criterion should be above 0.70 [30]. All CRs of the measurement models range from 0.844 to 0.951 . Convergent and discriminant validity were utilized to examine the construct validity [31]. Convergent validity required a factor loading of at least 0.50 and an Average Variance Extracted (AVE) above 0.50 [30], implying that more than half of the average variance of the indicators of a latent variable were explained. All factor loadings of the items were larger than 0.50 , and the AVE of destination image was 0.498 , close to 0.50 , and was considered as acceptable [28]. Table 4 reports the factor loadings, t-values, Average Variance Extracted (AVE), and Composite Reliability (CR), and it indicates an appropriate internal consistency.

Discriminant validity was essentially estimated by testing the correlations among the measures of potentially overlapping constructs. The square root of AVE from a construct needs to be higher than the variance shared between the construct and other constructs [29]. Table 5 shows all the correlations and square roots of AVEs. The results indicate an adequate discriminant validity.

Table 4. Reliability coefficients for the constructs

\begin{tabular}{|c|c|c|c|c|}
\hline Constructs and items & Factor loadings & T-value & AVE & CR \\
\hline \multicolumn{5}{|l|}{ First-order } \\
\hline Infrastructure & & & 0.644 & 0.942 \\
\hline IN1 & 0.799 & 35.267 & & \\
\hline
\end{tabular}




\begin{tabular}{|c|c|c|c|c|}
\hline IN2 & 0.803 & 35.615 & & \\
\hline IN3 & 0.809 & 39.798 & & \\
\hline IN4 & 0.770 & 27.844 & & \\
\hline IN5 & 0.785 & 27.622 & & \\
\hline IN6 & 0.834 & 35.978 & & \\
\hline IN7 & 0.791 & 32.003 & & \\
\hline IN8 & 0.836 & 47.984 & & \\
\hline IN9 & 0.792 & 30.738 & & \\
\hline Environment & & & 0.673 & 0.891 \\
\hline EN1 & 0.865 & 45.734 & & \\
\hline EN2 & 0.867 & 60.270 & & \\
\hline EN3 & 0.772 & 26.684 & & \\
\hline EN4 & 0.772 & 28.426 & & \\
\hline Accessibility & & & 0.651 & 0.882 \\
\hline $\mathrm{AC} 1$ & 0.827 & 25.727 & & \\
\hline AC2 & 0.842 & 38.718 & & \\
\hline $\mathrm{AC} 3$ & 0.774 & 26.456 & & \\
\hline $\mathrm{AC} 4$ & 0.782 & 30.034 & & \\
\hline Attractions & & & 0.644 & 0.844 \\
\hline AT1 & 0.778 & 14.730 & & \\
\hline AT2 & 0.769 & 26.227 & & \\
\hline AT3 & 0.856 & 48.004 & & \\
\hline Perceived Value & & & 0.829 & 0.907 \\
\hline P1 & 0.903 & 71.355 & & \\
\hline P2 & 0.918 & 85.223 & & \\
\hline Satisfaction & & & 0.805 & 0.925 \\
\hline
\end{tabular}




\begin{tabular}{|c|c|c|c|c|}
\hline S1 & 0.868 & 28.929 & & \\
\hline S2 & 0.921 & 90.852 & & \\
\hline S3 & 0.901 & 54.740 & & \\
\hline Loyalty & & & 0.815 & 0.930 \\
\hline L1 & 0.903 & 70.249 & & \\
\hline L2 & 0.925 & 90.852 & & \\
\hline L3 & 0.879 & 39.152 & & \\
\hline \multicolumn{5}{|l|}{ Second-order } \\
\hline Destination Image & & & 0.498 & 0.951 \\
\hline Infrastructure & 0.911 & 159.834 & & \\
\hline Environment & 0.708 & 41.246 & & \\
\hline Accessibility & 0.690 & 42.480 & & \\
\hline Attractions & 0.510 & 24.694 & & \\
\hline
\end{tabular}

Note: All loadings are significant at the $1 \%$ level $(p<0.001)$ with a 2000 sample bootstrapping.

Table 5. Discriminant validity

\begin{tabular}{lllll}
\hline & $\mathbf{1}$ & $\mathbf{2}$ & $\mathbf{3}$ & $\mathbf{4}$ \\
\hline Destination Image & $\mathbf{0 . 8 4 8}$ & & & \\
Loyalty & 0.633 & $\mathbf{0 . 9 0 3}$ & & \\
Satisfaction & 0.701 & 0.759 & $\mathbf{0 . 8 9 7}$ & $\mathbf{0 . 9 1 1}$ \\
Perceived Value & 0.608 & 0.618 & 0.645 & \\
\hline
\end{tabular}

Note: The square roots of average variance extracted (AVE) is shown on the diagonal in bold.

\subsection{Structure model and hypothesis testing}

Standardized path coefficients ( $\beta$ ), significance level (t-statistic), and $\mathrm{R}^{2}$ estimates were utilized to estimate the structural model.

Table 6 illustrates standardized path coefficients, t-value, and the test results. The estimates of the structural coefficients provide the foundation for testing. $\mathrm{H} 1$ and $\mathrm{H} 2$ predict that destination image has a significant and positive effect on perceived value and tourist satisfaction $(\beta 1=0.618, \mathrm{t}-$ value $=17.840, \mathrm{p}<0.001$ and $\beta 2=0.496$, $\mathrm{t}$-value $=9.162, \mathrm{p}<0.001$, respectively). Hence, $\mathrm{H} 1$ and $\mathrm{H} 2$ are supported. H3 predicts that destination image has no effect on tourist loyalty $(\beta 3=0.090, t$-value $=$ $1.739, \mathrm{p}>0.05)$; therefore, $\mathrm{H} 3$ is not supported. $\mathrm{H} 4$ and $\mathrm{H} 5$ predict that perceived value has a direct and positive effect on satisfaction and loyalty $(\beta 4=0.339, \mathrm{t}$-value $=5.764, \mathrm{p}<0.001$ and $\beta 5=0.194, \mathrm{t}$ - 
value $=3.106, \mathrm{p}<0.05$, respectively). Therefore, $\mathrm{H} 4$ and $\mathrm{H} 5$ are supported. $\mathrm{H} 6$ predicts that satisfaction has a direct and positive effect on loyalty $(\beta 6=0.571$, $\mathrm{t}$-value $=9.118, \mathrm{p}<0.001)$. Therefore, H6 is strongly supported.

$R^{2}$ value is used as an indicator of the overall predictive strength of the model. $R^{2}$ values are larger than the recommended criterion of 0.1 [28]. The $\mathrm{R}^{2} \mathrm{~S}$ of destination image, perceived value, satisfaction, and loyalty were $0.498,0.829,0.801$ and 0.815 , respectively, which indicate that the exogenous variable of each construct explained $49.8 \%, 82.9 \%, 80.1 \%$ and $81.5 \%$ of the variance of each construct, approximately.

$\mathrm{Q}^{2}$ value is described as an indicator of the model's predictive relevance. $\mathrm{Q}^{2}$ values larger than zero mean that the model has sufficient predictive relevance in relation to the endogenous variables. The cross-validated redundancy approach, as a measure of $\mathrm{Q}^{2}$, was recommended by Hair, using blindfolding procedures [29]. $\mathrm{Q}^{2}$ values for perceived value $(0.307)$, satisfaction $(0.430)$, and loyalty (0.489) were larger than zero, indicating substantial predictive relevance and explaining the endogenous latent variables. In addition, $\mathrm{Q}^{2}$ values for the first-order destination image indicators were all above 0.320 , suggesting the predictive relevance of the model to explain the first-order destination image variables.

Table 6. Results for the hypothesis model using PLS

\begin{tabular}{lllll}
\hline Hypothesis & Path coefficient & t-value & Support? \\
\hline Destination Image & Perceived Value & 0.618 & $17.840^{* * *}$ & Yes \\
Destination Image & Satisfaction & 0.496 & $9.162^{* * *}$ & Yes \\
Destination Image & Loyalty & 0.090 & 1.739 & No \\
Perceived Value Satisfaction & 0.339 & $5.764^{* * *}$ & Yes \\
Perceived Value Loyalty & 0.194 & $3.106^{* *}$ & Yes \\
Satisfaction Loyalty & 0.571 & $9.118^{* * *}$ & Yes \\
\hline
\end{tabular}

Note: A 2000 samples bootstrapping procedure was used. ${ }^{* *} p<0.01 ;{ }^{* * *} p<0.001$

\subsection{Direct, indirect, and total effects}

Table 7 indicates the direct, indirect, and total effects among destination image, perceived value, satisfaction, and loyalty. The effect of destination image on perceived value was entirely direct (0.618). The destination image construct had the largest and positive effect on satisfaction (0.706), followed by perceived value (0.339). Moreover, the positive effect of destination image on satisfaction was more direct $(0.496)$ than indirect $(0.210)$, through perceived value. However, the effect of perceived value on satisfaction was entirely direct (0.339). The effect of satisfaction on loyalty was also entirely direct (0.571). In addition, the direct effect of perceived value on loyalty (0.194) was equivalent to its indirect effect (0.193). The path coefficient between destination image and loyalty was not significant, but the total and indirect effects were found using a bootstrapping procedure. These results provide evidence of a sound predictive ability for the estimated endogenous latent variables and their underlying indicators. The mediating effects were tested through the Sober test.

Table 7. Direct, indirect, and total effects

\begin{tabular}{llll}
\hline & Direct effects & Indirect effects & Total effects \\
\hline
\end{tabular}




\begin{tabular}{|c|c|c|c|c|}
\hline Destination Imag & Perceived Value & 0.618 & 0.000 & 0.618 \\
\hline Destination Imag & Satisfaction & 0.496 & $0.210^{*}$ & 0.706 \\
\hline Destination Imag & Loyalty & 0.090 & $0.522^{*}$ & 0.612 \\
\hline Perceived Value & Satisfaction & 0.339 & 0.000 & 0.339 \\
\hline Perceived Value & Loyalty & 0.194 & $0.193^{*}$ & 0.387 \\
\hline Satisfaction Loy & alty & 0.571 & 0.000 & 0.571 \\
\hline
\end{tabular}

Note: ${ }^{*} p<0.05$ by Sober testing procedure

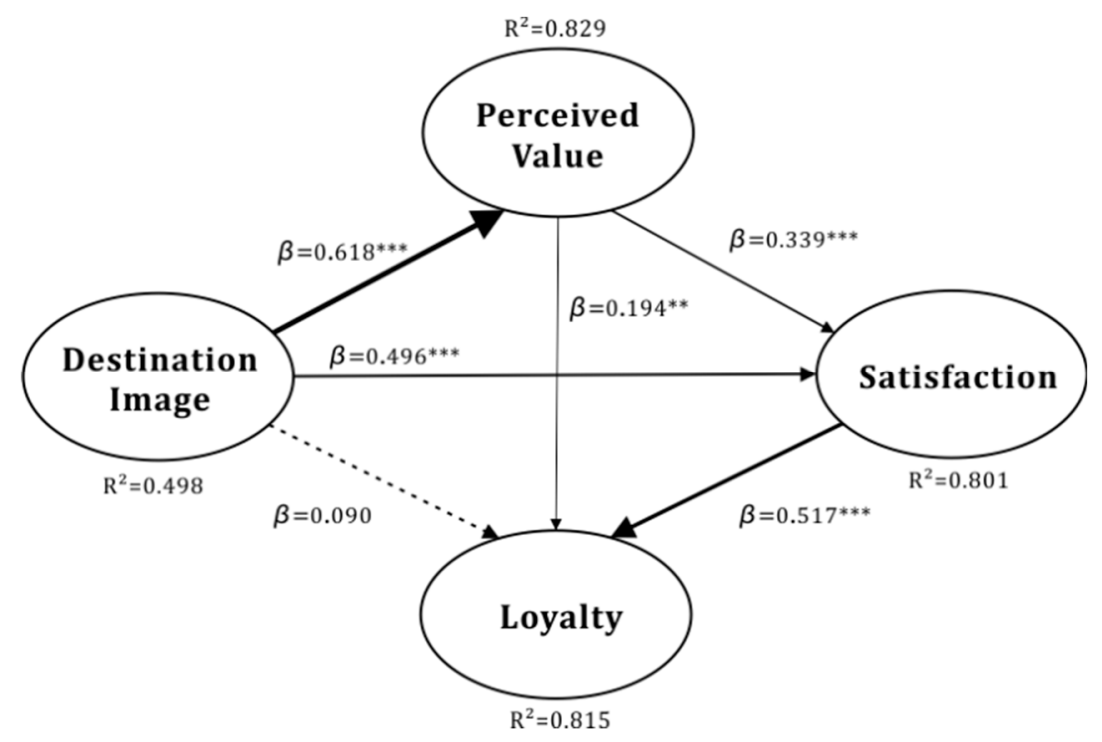

Figure 2. Results of destination loyalty model

Note: Direct influence uses solid line, and line width indicates the degree of influence; no influence uses broken line.

\subsection{Mediating effect of perceived value and satisfaction}

Table 7 shows that the indirect effect of destination image on tourist loyalty is 0.522 , which implies a mediating effect of perceived value and satisfaction. The analysis of classic causal step approach was employed to assess the mediation effect, as in Baron and Kenny (1986). Four conditions must be met to establish mediation: (1) a direct link between the independent variable and dependent variable; (2) the independent variable must be related to mediating variables; (3) the mediator should be significantly related to the dependent variable when both independent and mediating variables are predictors of the dependent variable; (4) the relationship between the independent variable and dependent variable must be significantly reduced when the mediator is added.

Table 8 indicates that the relationship between destination image and tourist loyalty is significantly reduced when perceived value and satisfaction are controlled for, through the calculation of Step 4 . The Bata coefficient between destination image and tourist loyalty was clearly reduced, from $0.612(p<0.001)$ in Step 1 to $0.032(p>0.05)$ in Step 4. Therefore, H7 is supported. Finally, the strength of this mediation needs to be determined by using the Variable Accounted For (VAF). VAF determines the size of the indirect effect with respect to the total effect. When VAF is above $80 \%$, there is full mediation. A situation in which VAF is larger than $20 \%$ and less than $80 \%$ indicates a partial mediation. Otherwise, the mediation effect does not exist. As indicated in Table 7, 
VAF is $85.3 \%$. Therefore, the findings of the mediation tests support the full mediating effect of perceived value and tourist satisfaction between destination image and tourist loyalty.

Table 8. Mediation tests using PLS

\begin{tabular}{llc}
\hline Steps of mediating effect & Beta & T-value \\
\hline Step 1: Independent variable to outcome variable & & \\
Destination Image-Loyalty & 0.612 & $17.374^{* * *}$ \\
Step 2: Independent variable to mediators & & $17.929^{* * *}$ \\
Destination Image-Perceived Value & 0.619 & $19.603^{* * *}$ \\
Destination Image-Satisfaction & 0.707 & 0.787 \\
Step 3 and Step 4: Independent variable and mediators to outcome variable & & $3.088^{* *}$ \\
Destination Image-Loyalty & 0.032 & $8.748^{* * *}$ \\
Perceived Value-Loyalty & 0.193 & 0.574 \\
Satisfaction-Loyalty
\end{tabular}

${ }^{* *} p<0.01 ; * * *<0.001$

\section{Discussion and conclusions}

\subsection{Theoretical implications}

This study contributes to the literature by investigating the factors that are likely to influence Chinese tourists' destination loyalty from a new perspective. The relationships among destination image, perceived value, tourist satisfaction, and tourist loyalty are analyzed on the basis of practical experience. The results showed that perceived value, destination image, and satisfaction are all antecedents of destination loyalty. Most importantly, the mediating role of perceived value and satisfaction can not be ignored.

A significant relationship between destination image and perceived value was found in this study, in line with the findings of previous studies [19]. Moreover, destination image and satisfaction are examined, and a positive relationship is found between the two items [32]. However, a statistically not significant relationship between destination image and loyalty was found in this study.

A significant relationship between perceived value and satisfaction was found. Mixed results on this topic exist in the literature. For example, Kashyap and Bojanic found a significant relationship between perceived value and loyalty [33]. Chen found a significant direct relationship between perceived value and satisfaction for heritage tourists, which is consistent with our study's results [21]. Moreover, a significant relationship between perceived value and loyalty was found in our study. In contrast, Howat and Assaker did not find a significant direct relationship between perceived value and loyalty [34].

A significant relationship between satisfaction and loyalty was tested. This study has demonstrated that satisfaction has a positive effect on loyalty and the findings are consistent with past studies [34,35]. 
The mediation effect of perceived value and tourist satisfaction on the relationship between destination image and loyalty was examined. For example, Wang and Zhang found that perceived value mediates the relationship between destination image and tourist satisfaction [36]. The findings of this study confirmed perceived value as a mediating variable between destination image and loyalty. In addition, the results of this study found that perceived value has both direct and indirect influences on tourist loyalty. Perceived value and tourist satisfaction mediate the relationship between destination image and tourist loyalty [21].

\subsection{Managerial implications}

The results of this study have significant managerial implications. Firstly, this study found four underlying dimensions of destination image, which seem to be fundamental elements that contribute to tourists' satisfaction and loyalty. In particular, "Infrastructure" (factor 1) accounts for about $50 \%$ of the variances explained in "destination image." The construction of infrastructure facilities (campgrounds, service stations, information centers) has been accelerated to elevate Xinjiang to a "world-class" international tourism destination. As the same time, environment (factor 2), accessibility (factor 3), and attractions (factor 4) are all important elements to develop tourism in China.

Secondly, tourism marketers and managers should develop promotional activities and events in order to appeal to domestic tourists. For example, the central government has hosted or sponsored various events for tourism promotion purposes. For example, it has successfully held "the selfdriving car and recreational vehicle industrial development conference," "the international special tourism festival," "the international tourism festival," and "the western China ice and snow tourism festival." These promotional activities matched the goal to develop Xinjiang into a "tourist distribution center of the Silk Road Economic Zone."

With the country's rapidly growing economy, car trip in China has become a new trend. Meanwhile, China possesses abundant tourist resources in Xinjiang area, such as Tianshan (World Natural Heritage Site), Silk Road (World Cultural Heritage Site), Altai Mountains, and Taklimakan Desert. Figure 3, Figure 4 and Figure 5 show the beautiful scenery in Xinjiang. These are all important factors in the development of Tourism.

Tourism administrators need to accelerate infrastructure construction to enhance destination image, and focus on tourist satisfaction in order to establish tourist loyalty. At the same time, marketers should actively develop new markets and customers in the field of car trip. Finally, keeping a balance between developing tourism and conserving the unique natural and cultural heritage is key to achieve the sustainable development of the tourism industry.

\subsection{Limitations and suggestions}

Like other studies, this study has several limitations. Firstly, the data used in this study only cover a short period. Therefore, the findings of this study may not reflect seasonal variations. In addition, the small sample size does not allow the generalization of the results of this study. Consequently, the findings should be interpreted with caution. Secondly, there may exist other factors affecting tourist loyalty, beyond "destination image," "perceived value," and "tourist satisfaction." Other potential antecedents should be explored in future studies. Last, the number of research questions should be increased (or decreased) in future studies. Therefore, destination image may include other constructs, which should be analyzed by Exploratory Factor Analysis. 


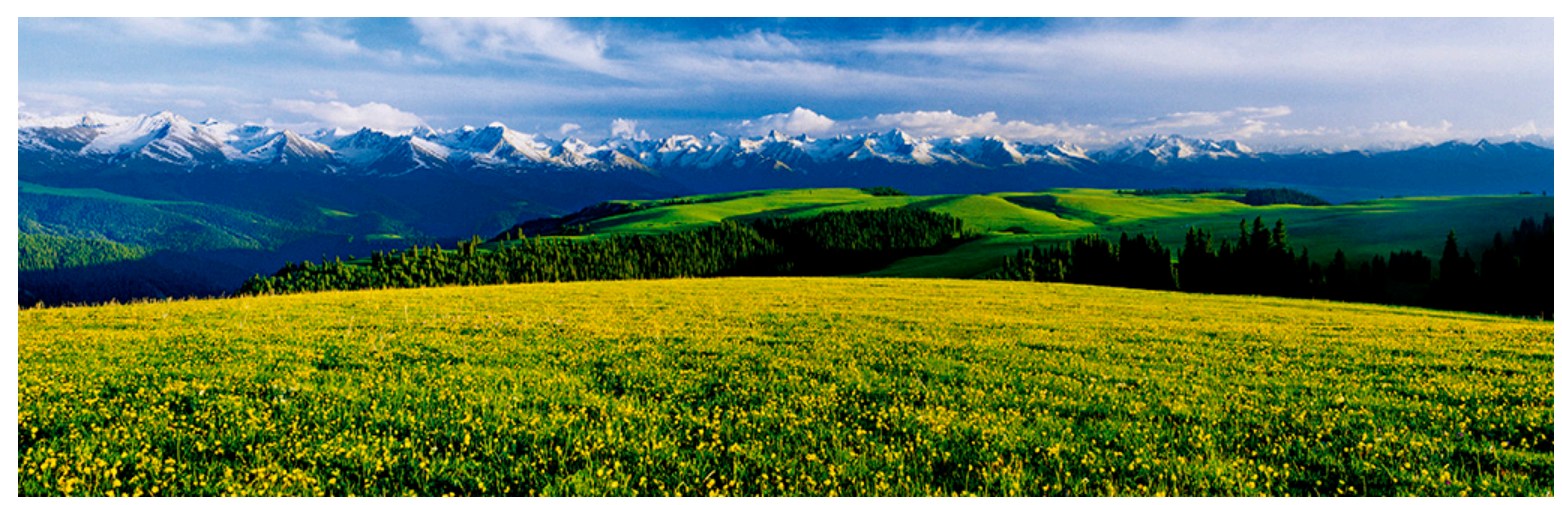

Figure 3. Karajun - World Natural Heritage

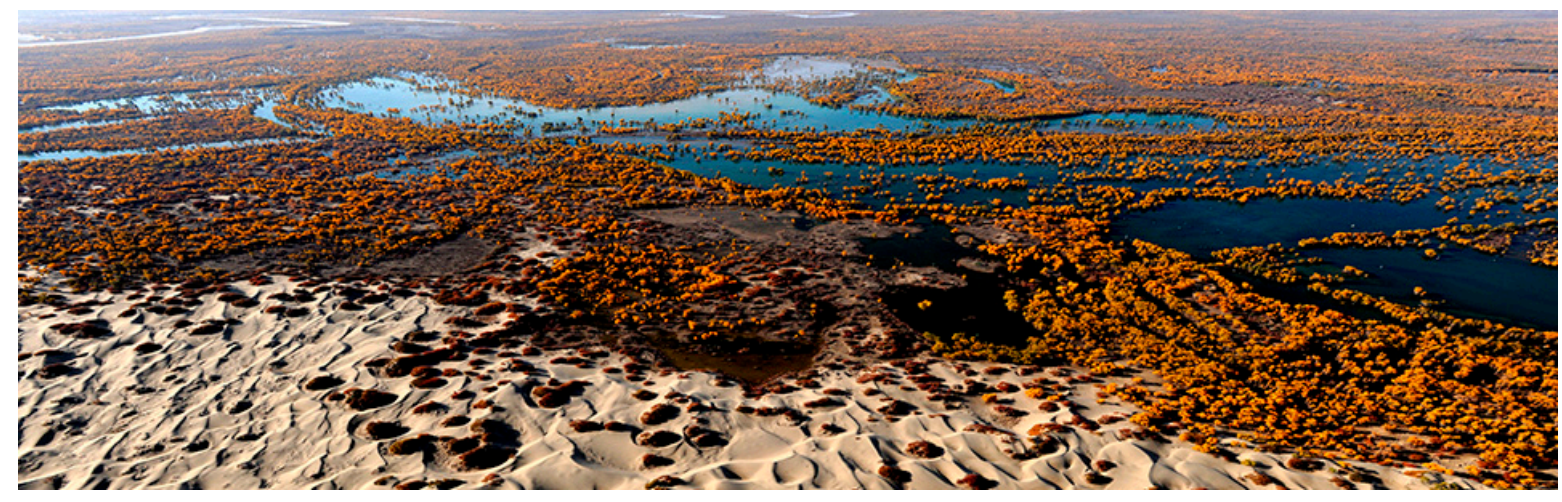

Figure 4. Luntai Populus Euphratica Forest

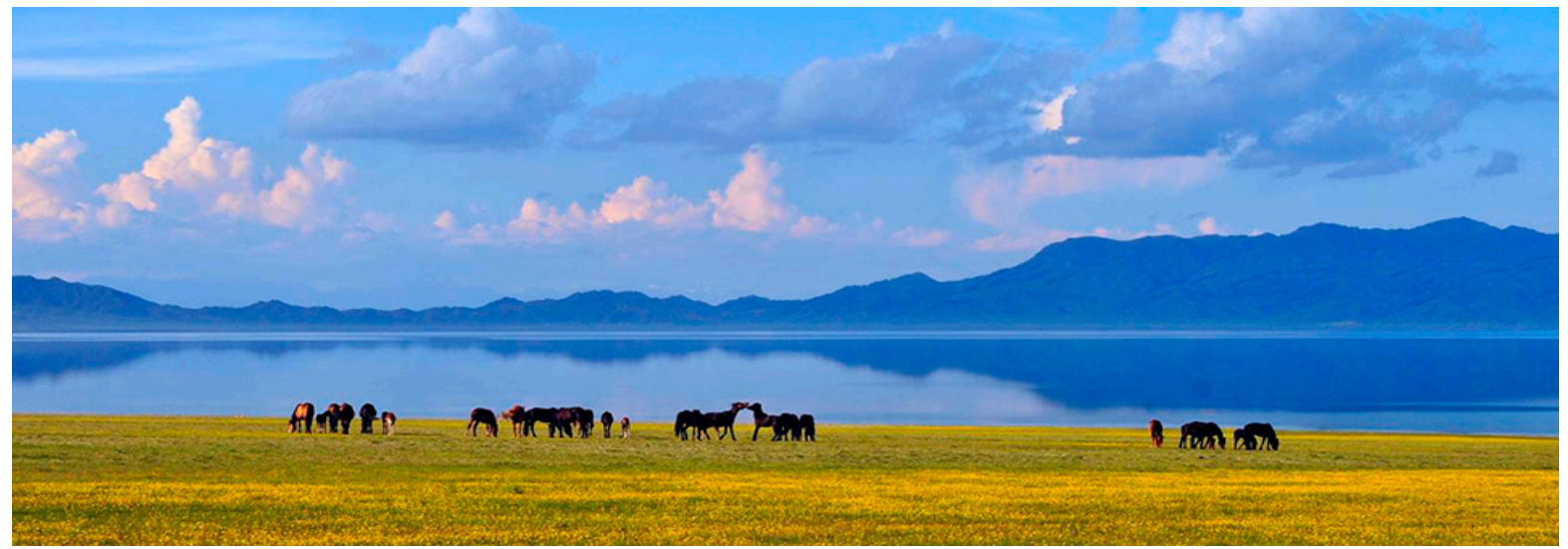

Figure 5. Koktokay

Note: The above photos are photographed by Zhangping Yang. 
Acknowledgments: The research was funded by the Science and Technology Service Network Initiative of CAS (KFJ-SW-STS-181) and the National Natural Science Foundation of China (No. 41301163).

Author Contributions: All authors contributed to designing the research and the questionnaire, as well as writing the manuscript. Bin Wang, Fang Han, Hui Shi carried out the survey. All authors read and approved the final manuscript.

Conflicts of Interest: The authors declare no conflict of interest.

\section{References}

1. Prideaux, B.; Carson, D. Drive tourism: trends and emerging markets. Drive Tourism Trends \& Emerging Markets, 2010. 33(5): p. 1288-1289.

2. Prideaux, B.; Carson, D. A framework for increasing understanding of self-drive tourism markets. Journal of Vacation Marketing, 2003. 9(4): p. 307-313.

3. Guo, L. A new appraisement and exploitation strategy of Xinjiang tourism resources. Yunnan Geographic Environment Research, 1993. 5(2): p. 17-21.

4. Xu, X.; Yang, Z.; Saiken, A.; Rui, S.; Liu, X. Natural Heritage value of Xinjiang Tianshan and global comparative analysis. Journal of Mountain Science, 2012. 9(2): p. 262-273.

5. Lee, C.K.; Yoon, Y.S.; Lee, S.K. Investigating the relationships among perceived value, satisfaction, and recommendations: The case of the Korean DMZ. Tourism Management, 2007. 28(1): p. 204-214.

6. Ryu, K.; Han, H.; Kim, T.H. The relationships among overall quick-casual restaurant image, perceived value, customer satisfaction, and behavioral intentions. International Journal of Hospitality Management, 2008. 27(3): p. 459-469.

7. Echtner, C.M.; Ritchie, J.R.B. The measurement of destination image: an empirical assessment. Journal of Travel Research, 1993. 31(4): p. 3-13.

8. Gallarza, M.G.; Saura, I.G.; GarcíA, H.C. Destination image: Towards a Conceptual Framework. Annals of Tourism Research, 2002. 29(1): p. 56-78.

9. Sanz Blas, S.; Carvajal-Trujillo, E. Cruise passengers' experiences in a Mediterranean port of call. The case study of Valencia. Ocean \& Coastal Management, 2014. 102, Part A: p. 307-316.

10. Toudert, D.; Bringas-Rábago, N.L. Impact of the destination image on cruise repeater's experience and intention at the visited port of call. Ocean \& Coastal Management, 2016. 130: p. 239-249.

11. Sun, X.; Geng-Qing, C.; Xu, H. Developing destination loyalty: The case of Hainan island. Annals of Tourism Research, 2013. 43: p. 547-577.

12. Stylos, N.; Vassiliadis, C.A., Bellou,V.; Andronikidis, A. Destination images, holistic images and personal normative beliefs: Predictors of intention to revisit a destination. Tourism Management, 2016. 53: p. 40-60.

13. Petrick, J.F. Development of a multi-dimensional scale for measuring the perceived value of a service. Journal of Leisure Research, 2002. 34(2): p. 119-134.

14. Boksberger, P.E.; Melsen, L. Perceived value: a critical examination of definitions, concepts and measures for the service industry. J Serv Mark. Journal of Services Marketing, 2011. 25(3): p. 229-240.

15. Duman, T.; Mattila, A.S. The role of affective factors on perceived cruise vacation value. Tourism Management, 2005. 26(3): p. 311-323.

16. Chen, C.F.; Tsai, D.C. How destination image and evaluative factors affect behavioral intentions? Tourism Management, 2007. 28(4): p. 1115-1122.

17. Clemes, M.D.; Brush, G.J.; Collins, M.J. Analysing the professional sport experience: A hierarchical approach. Sport Management Review, 2011. 14(4): p. 370-388. 
18. Li, X.; Petrick, J.F. Towards an integrative model of loyalty formation: the role of quality and value. Leisure Sciences, 2010. 32(3): p. 201-221.

19. Kim, S.H.; Holland, S.; Han, H.S. A Structural Model for Examining how Destination Image, Perceived Value, and Service Quality Affect Destination Loyalty: a Case Study of Orlando. International Journal of Tourism Research, 2013. 15(4): p. 313-328.

20. Song, H.; van der Veen, R.; Li, G.; Chen, J.L. The Hong Kong tourist satisfaction index. Annals of Tourism Research, 2012. 39(1): p. 459-479.

21. Chen, C.F.; Chen, F.S. Experience quality, perceived value, satisfaction and behavioral intentions for heritage tourists. Tourism Management, 2010. 31(1): p. 29-35.

22. Reisinger, Y.; Turner, L.W. Cross-cultural behaviour in tourism: concepts and analysis. Tourism \& Hospitality Research, 2005. 5(4): p. 372-373.

23. Rasoolimanesh, S.M.; Dahalan, N.; Jaafar, M. Tourists' perceived value and satisfaction in a communitybased homestay in the Lenggong Valley World Heritage Site. Journal of Hospitality and Tourism Management, 2016. 26: p. 72-81.

24. Oliver, R.L. Whence Consumer Loyalty? Journal of Marketing, 1999. 34(1): p. 33-44.

25. Rundle-Thiele, S. Exploring loyal qualities: assessing survey-based loyalty measures. Journal of Services Marketing, 2013. 19(7): p. 492-500.

26. Wendy-Gao, B.; Lai, I.K.W. The effects of transaction-specific satisfactions and integrated satisfaction on customer loyalty. International Journal of Hospitality Management, 2015. 44: p. 38-47.

27. Forgas-Coll, S.; Palau-Saumell,R.; Sánchez-García, J.; Callarisa-Fiol, L.J. Urban destination loyalty drivers and cross-national moderator effects: The case of Barcelona. Tourism Management, 2012. 33(6): p. 13091320.

28. Cevdet Altunel, M.; Erkut, B. Cultural tourism in Istanbul: The mediation effect of tourist experience and satisfaction on the relationship between involvement and recommendation intention. Journal of Destination Marketing \& Management, 2015. 4(4): p. 213-221.

29. Hair, J.F.; Hult, G.T.M.; Ringle, C.M.; Sarstedt, M. A Primer on Partial Least Squares Structural Equation Modeling (PLS-SEM) (1st), 2014. USA: Sage Publications.

30. Fornell, C.; Larcker, D.F. Evaluating Structural Equation Models with Unobservable Variables and Measurement Error. Journal of Marketing Research, 1981. 18(1): p. 39-50.

31. Chin, W.W.; Gopal, A.; Salisbury, W.D. Advancing the Theory of Adaptive Structuration: The Development of a Scale to Measure Faithfullness of Appropriation. Information Systems Research, 1997. 8(4): p. 342-367.

32. Assaker, G.; V.E. Vinzi; O'Connor, P. Examining the effect of novelty seeking, satisfaction, and destination image on tourists' return pattern: A two factor, non-linear latent growth model. Tourism Management, 2011. 32(4): p. 890-901.

33. Kashyap, R.; Bojanic, D.C. A Structural Analysis of Value, Quality, and Price Perceptions of Business and Leisure Travelers. Journal of Travel Research, 2000. 39(1): p. 45-51.

34. Howat, G.; Assaker, G. The hierarchical effects of perceived quality on perceived value, satisfaction, and loyalty: Empirical results from public, outdoor aquatic centres in Australia. Sport Management Review, 2013. 16(3): p. 268-284.

35. Vosta, L.N.; Pool, J.K.; Jalilvand, M.R.; Nafchali, J.S. The effect of marketing constructs and tourists' satisfaction on loyalty to a sport destination: A structural equation model and analysis. Education Business \& Society Contemporary Middle Eastern Issues, 2014. 7(4): p. 316-332. 
36. Wang, X.; Zhang,J.; Gu, C.; Zhen,F. Examining Antecedents and Consequences of Tourist Satisfaction: A Structural Modeling Approach. Tsinghua Science \& Technology, 2009. 14(3): p. 397-406.

37. Baron, R.M.; Kenny, D.A. The moderator-mediator variable distinction in social psychological research: Conceptual, strategic, and statistical considerations. Journal of Personality and Social Psychology, 1986. 51(6): p. 1173-1182.

(C) 2016 by the authors; licensee Preprints, Basel, Switzerland. This article is an open access article distributed under the terms and conditions of the Creative Commons by Attribution (CC-BY) license (http://creativecommons.org/licenses/by/4.0/). 